\title{
On the Investigation of Taste Adjectives in Linguistics
}

\section{Laman Maharram Gasimli}

\author{
Azerbaijan National Academy of Sciences, Nasimi Institute of Linguistics, Baku, Azerbaijan \\ Email: kasimli118@hotmail.com
}

Doi:10.5901/mjss.2016.v7n3s1p303

\begin{abstract}
The article investigates different opinions expressed in general and Azerbaijani linguistics connected with the definition and semantic volume of the adjective as a part of speech. The consideration of issues related to words denoting quality and property of a noun, quite different opinions of the world linguists allow us to conclude that there are almost identical and fairly controversial picture in the investigation of the adjective as a part of speech. One of the semantic groups of adjectives, i.e. taste adjectives has been repeatedly investigated in modern linguistic researches on the basis of a particular language, as well as of different languages. Although researchers paid considerable attention to the adjectives denoting taste, a number of issues such as the words attributable to the structure and scope of microfield denoting taste which included the words of quality have not been solved yet. First of all, it should be noted that the terminological units used for naming adjectives that are included in this area reflects the diversity. In different languages taste adjectives are named under different terms. The outcome of the study could be useful in teaching semantic groups of the adjective.
\end{abstract}

Keywords: linguistics, Azerbaijani language, adjective, taste adjectives.

\section{Introduction}

Acquaintance with linguistic literature published in different languages lately shows that interest to investigation of lexical units expressing the human feelings is growing. The human gains information about surrounding environment through the influence of objects, events and processes in reality to his sense organs. Feelings are the first link in the formation of images about environment and all other kinds of human cognitive performance arise from them.

There are a lot of research works, dissertations, monographs and articles dedicated to the adjectives denoting color, light, touch, hearing and smell. (See: Beloborodova, 2000; Gadani, 1984; Gourdov, 1972; Dybo, 2002; Granovskaya,1964; Ruzin, 1994; Merzlyakova, 2003; Corbett \& Morgan, 1988).

The sense of taste has a special place among the empirical feelings and plays an important role in the body's reactions to foreign stimuli, and has great emotional and psychological significance for human beings. The vocabulary which serves to express the sense of taste has a special place among the lexical units expressing human feelings. These words have many times been under research. The sense of taste plays an important role in the life of a person.

The words denoting taste, i.e. taste adjectives have repeatedly been investigated in modern linguistic researches on the materials of a particular language, as well as of different languages. Although the researchers paid considerable attention to the taste adjectives, a number of issues referred to the words that can be attributed to the structure of the microfield, denoting taste, remain unsolved. The aim of this paper is to consider the aspects of investigation of the words denoting the quality in general, and particularly the adjectives of taste in Azerbaijani linguistics and compare it in the context of general linguistics.

\section{Discussion}

First of all, it should be noted that the terminological units used for naming adjectives that are included in this area reflect diversity. Thus, words belonging to this group of the adjective in English linguistics are named "adjectives of taste", "taste adjectives", "gustative adjectives", "gustatory adjectives" (http://www.vocabulary.com/dictionary/gustatory), "sensory adjectives belonging to the gustative domain" (Salamon, 2011).

In Russian linguistics, together with the variety of terms, fragmentation can be observed: прилагательные с первичным вкусовым значением "adjectives with primary gustatory value" (Shirina, 1971), прилагательные вкусообозначения "adjectives denoting taste" (Kutsenko, 1979), прилагательные со значениями вкусовых ощущений "adjectives with the values of taste sensations", прилагательные вкусового ощущения "adjectives sense of taste" 
(Wiseman, 1980; Gerasimova, 1985), прилагательные вкуса "taste adjectives" (Lechitskaya, 1985).

In Azerbaijan linguistics, in connection with these words we find the following terms: dad bildirən sifətler "taste adjectives" or "adjectives of taste" (Budaqova, 1985:137; Naghisoylu \& Zeynalli, 2009: 57), dad sifətləri "gustatory adjectives" (Budaqova, 1985:137), dad məfhumu bildirən sifətlər "adjectives denoting notion of taste" (Aliyeva, 2010:213], dad ifadə edən sifətlər "adjectives expressing taste", dad əlamətlərini ifadə edən sifətlər "adjectives indicating gustatory signs" (Aliyeva, 2010:236-237).

As is seen, the picture observed in naming adjectives terminologically in Azerbaijani linguistics is the same as compared to the situation observed in English and Russian linguistics. For terminological naming of adjectives in Azerbaijan linguistics only one of the above-mentioned four terms - the taste adjectives - is able to express the content of substance, while others are useless in the terminological naming of the adjectives used for this purpose. Therefore, the "taste adjectives" term can be considered more acceptable.

One of the issues to be emphasized is that there is not a standard classification of taste adjectives based on the materials of different languages. In the existed studies, the researchers, taking into consideration the semasiological (i.e. on the basis of semantic component) and onomasiological principles (i.e. relationship of the meaning of the word with certain notion), divided adjectives into a concrete group. In this case both the adjectives denoting the sense of taste and adjectives characterizing, describing the sense of taste are assigned to the same group.

For example, in the differentiation of a group of the taste adjectives in the Russian language, K.M.Gerasimova uses such a proposition as a basis: if the notion of taste itself is continuous and discrete from semantic point of view, then all the adjectives characterize the sense of taste are continuous and discrete. The discreteness of general semantic indications of taste adjectives gave the researcher the opportunity to distinguish several sub-groups in the frame of general group. For this reason, in the classification presented by the researcher not only the taste adjectives, but also such words in Russian as знакомый "familiar", незнакомый "unfamiliar" which create phrases with the word вкус "taste" have been included to the group of the taste adjectives (Gerasimova, 1985). It shows that there are not certain criteria of classification of taste adjectives in the conducted investigation.

The classification proposed by A.V.Kutsenko who researched the semantic structure of taste adjectives and their lexical compatibility in Russian and English, draws attention in terms of above-mentioned classification of adjectives. This classification is different from others in terms of the concreteness and accuracy of classification criteria. The researcher divides taste adjectives to the following groups:

1. Adjectives denoting simple taste norm - горький, сладкий, кислый / bitter, sweet, sour, acid, tart.

2. Adjectives denoting complex taste norm - кисло-сладкий, горько-соленый / bitter-sweet, sweet-sour;

3. Adjectives denoting differentiated complex taste norm - горько-вяжущий / acerb;

4. Adjectives expressing non-differentiated complex taste norm - pungent.

5. Adjectives expressing weak intensity which stating with suffixes - солоноватый, кисленький / bitterish;

6. Adjectives expressing high intensity of taste - приторный / luscious (Kutsenko, 1979).

As is seen, in the classification of adjectives, the researcher refers to a certain "norm" or "degree". The "norm" or "degree" can also be called the etalon. It should be noted that the "norm" or "degree" does not only exist for the taste adjectives, but also for all the words denoting quality. Because of this, each item is different in their characteristics and qualities characterizing them. Diversity is typified and generalized in our consciousness in the process of understanding the real existed sign or quality. Generalization happens on the basis of the association with the "norm" or "degree" of quality, perceived by our sense organs, which, exist in our consciousness for different things or their class. That "norm" or "degree", i.e. the etalon is an idea or conception that is associated with the quality of the real object, perceived by the organs of sense. The etalon bears a subjective-objective character.

Based on the foregoing, the mechanism of the expression of taste quality can be described as following: there exist notions of taste qualities in the mind of the bearers of any language. When receiving an stimulation by taste organs, a signal is sent to the corresponding center of the brain, and, by searching among the existing taste notions in the mind of the bearer of language, the appropriate one is found. As a result, it is expressed with the adjective appropriate to the quality of that object.

Studying the adjective as a part of speech in terms of the nomination in the modern Russian language, J.V.Levitskaya notes that "the concept of every people of a particular taste is associated with various "reference objects". For example, Russians associate bitter taste with flavor of quinine, absinth sage, Lithuanians - with a taste of pepper, and the British - the flavor of orange peel or taste of coffee" (Lechitskaya, 1985).

The semes "evaluation" and "intensity" can be a part of the lexical meaning, or by forming the periphery can indicate the appearance intensity of taste quality, and can show the speaker's evaluative attitude of the expressed quality.

Some researchers who studied the semantics of adjectives try to define a set of semes basing on relevant word or 
concepts. For example, considering taste adjectives from structural and semantic point of view in modern Russian language, L.I.Shirina defines a set of semes or a set of distinctive features known in physiology (Shirina, 1971).

One of the researches dedicated to the study of taste adjectives in lingvo-cognitive plan belongs to T.M.Matveyeva. Her research object is the lexical units of taste and taste evaluation in the German language. The researcher tries to reveal the content and specification of taste category as one of the main perceptive categories, to characterize linguistic means of its realization, and to show lingvo-cognitive characteristics. T.M.Matveyeva's research shows that the category of taste is among the perceptive categories that are of critical importance for the processes of conceptualization and realization of surrounding world. (Matveyeva, 2005:5).

The main importance of the research can be explained by the fact that the obtained results are confirmed on the basis of the latest achievements in modern linguistics. With the help of the lingvo-psychological methods the researcher comes to a conclusion that perceptive structures belong to the categories of quality and they are bound for human being. Perceptive structures demonstrate that the information is dependent on access to information channels and penetrate the structure of the emotional and evaluation relation. In this research where the author displayed a field approach to the perceptive category, it is shown that the category of taste rests upon the concept of "taste", and the category of taste has its content form and expression form. For the representation of the content of the categorical concept of "taste", the method of distinguishing conceptual qualities or traits is considered to be more adequate. The conceptual qualities or traits are considered the followings and they are formed on the bases of expressions in the language: 1) the presence of contact; 2) ability to be accepted; 3) the degree of expression (strong, weak); 4) natural // artificial character; 5) proximity to prototype; 6) // unpleasant/tasty; 7) suitable // unfit for food. (Matveyeva, 2005:9).

T.M.Matveyeva distinguishes two groups of taste in cognitive plan - primary and non-primary. Primary tastes are accepted only by the means of taste receptors and they are in monomodal, but non-primary tastes are of polymodal character (Matveyeva, 2005:11).

One of the researchers who investigated taste adjectives is M.P.Bilous. His investigation is fulfilled on materials of the modern Ukrainian language. As the result of investigation of taste adjectives in the modern Ukrainian language, the language means for expressing taste are revealed, semantics of ready-made adjective constructions available in the Ukrainian language, regularities of the nomination process belongs to this language are learnt, onomasiological and semasiological characteristics of taste names are given, types of taste names according to the methods and sources of nominations are defined. (Bilous, 1985).

While discussing taste adjectives M.I.Qinatulin's research should be mentioned. In his work "The Semantics of Words and Sense Organs" he spoke of 5 sensor archisemems, and made an interesting effort to classify the vocabulary from this point of view. These archisemems comprise vision, hearing, tactile, smell and taste. Taking into consideration the interconnection and stipulation of two stages of cognition, i.e. sensitive cognition and abstract thinking, the researcher comes to an end that the semantic side of the language, in accordance with the mentioned archisemems, can be divided into five semantically capacious units (Ginatulin, 1972).

In Azerbaijani linguistics, the taste adjectives have not been studied monographically, but they have been reviewed superficially in a number of grammar books, textbooks and articles written in Azerbaijani language. For example, speaking of simple adjectives, M.Husseinzade enumerated five groups of adjectives and one group of them comprises taste adjectives: "q) Denoting taste - şirin (çay) "sweet (tea)", acı (istiot) "bitter (pepper)", turş (alça) "sour (cherry-plum, alycha", şor (xörək "salt (meal)" (Husseinzade, 1983:75).

Azerbaijani scholar A.Damirchizade spoke of a separate group of "sign and quality adjectives perceived by taste and tactile organs" while determining the semantic types of adjectives (Shiraliyev, 1951:124).

Y.Seyidov does not mention taste adjectives separately. From such examples as "acı "bitter", şirin "sweet", turş "sour", möhkəm "firm, strong, steady, stable", bərk "hard, solid" presented by the researcher, it is possible to see that taste adjectives have been included into the group of "adjectives denoting different qualities of things" (Seyidov, 2002:269).

Q.Kazimov does not distinguish a separate group of taste adjectives either. He mentions that taste adjectives bear a quality character, and includes them into the semi-group entitled "adjectives denoting quality by perceiving taste, hearing, sense, tentacles members (Kazımov, 2010:100).

A part of N.Aliyeva's research comprises the adjectives denoting the notion of taste in the English language and their means of expression in the Azerbaijani language (Aliyeva, 2010:236-270).

\section{Conclusion}

Thus, having considered the investigation aspects of words denoting quality in Azerbaijani linguistics and its comparison 
in the context of general linguistics provides the basis for such a conclusion that both in Azerbaijani and general linguistics approximately the same and quite controversial panorama is observed in approach to the adjective as a part of speech. The main feature in determining the taste adjectives both in semantic plan and studying them in the aspect of using within the context is the dependence of this word group from semantic point of view. As the lexicon serving to express the sense of taste takes special place among linguistic units denoting the sense and feeling of human being, the interest shown to study them, first of all, based on such a fact that adjectives, included to this thematic group, act as the main means of expression of the notion "taste" which has vital importance for human being, while the semantics of taste adjectives reflects a separate microsystem of knowledge about the world.

\section{References}

Aliyeva, N. (2010). The Adjective in the English language. Baku: Elm and Tahsil.

Beloborodova, I.V. (2000). The Concept of "Color" in Lingvocognitive Aspect (based on an autobiographical prose). Abstract of Ph.D. thesis. Taganrog.

Bíborka Szántó (Salamon). Synaesthesia. A Cognitive Approach. Abstract of Ph.D. thesis. [Online] Available: http://doctorat.ubbcluj.ro/ sustinerea_publica/rezumate/2011/filologie/ SalamonBiborkaEn.pdf

Bilous, M.P. (1985). Adjectives of Taste in the Modern Ukrainian Language. Abstract of Ph.D. thesis. Lvov.

Budaqova, Z. (ed.) (1985). The Semasiology of the Modern Azerbaijani Language. Essays. Baku: Elm.

Corbett, G.G., Morgan, G. (1988). Color Terms in Russian: Reflections of Typological Constraints in a Single Language. Journal of linguistics, 24, 31-64.

Dybo, A.V. (2002). Basic Color Terms in the Celtic languages. Moscow Linguistic Journal. v. 6. i. 1, 7 - 52.

Gadani, K. (1984). Comparative Characteristics of the Adjectives of Color in some Slavic Languages. Abstract of Ph.D. thesis. Minsk.

Gerasimova, K.M. (1985). Lexicographic and Semantic Interpretation of Adjectives of Taste Sensations. Abstract of Ph.D. thesis. Moscow.

Ginatulin, M.M. (1972). The Semantics of Words and Sense Organs. Foreign Philology, 1. Alma-Ata.

Gourdov, A. (1972). The Semantic Structure of English Adjectives white, black and Turkmen ak kara and their Derivation Potential in the Compared Languages. Abstract of Ph.D. thesis. Moscow: Moscow State Pedagogical Institute.

Granovskaya, L.M. (1964). The Adjectives Denoting Color in the 17-20th century Russian Language. Abstract of Ph.D. thesis. Moscow.

Gustatory. [Online] Available: http://www.vocabulary.com/dictionary/gustatory

Husseinzade, M. (1983). Modern Azerbaijani Language. Morphology. Part 3. Baku: Maarif.

Kazimov, G.Sh. (2010). Modern Azerbaijani Language. Morphology. Baku: Nurlan.

Kutsenko, A.V. (1979). Semantic Structure of the Taste Adjectives and their lexical compatibility in English and Russian. Abstract of Ph.D. thesis. Moscow.

Lechitskaya, J. B. (1985). Adjectives of taste in the modern Russian language (in terms of the nomination). Abstract of Ph.D. thesis. Moscow.

Matveyeva, T.M. (2005). Perceptual Category of Taste and Linguistic means of its Expression. Abstract of Ph.D. thesis. Chelyabinsk.

Merzlyakova, A.H. (2003). The Secondary Function of Perceptual Adjectives (based on Eng., Rus., and French Language). Izhevsk: Udmurt State University.

Naghisoylu, M., Zeynalli, M. (2009). The Azerbaijani language. Baku.

Ruzin, I.G. (1994). Cognitive Strategy of Naming: modes of perception (vision, hearing, touch, smell, taste), and their expression in language. Voprosy Yazykoznaniya, 6, 79-100.

Seyidov, Y. (2002). The Grammar of the Azerbaijani language. Morphology. (2nd ed.). Baku: Baku University Press.

Shiraliyev, M. (ed.) (1951). The Grammar of the Azerbaijani Language. Part I. Baku.

Shirina, L.I. (1971). Adjectives of Taste in Modern Russian: An Experience of Structural and Semantic research. Abstract of Ph.D. thesis. Tashkent.

Wiseman, N. (1980). Semantic nature of sensory adjectives in the French and Russian languages. Abstract of Ph.D. thesis. Alma-Ata. 